(1)
Volume 6, Nomor 2, Tahun 2020
Tersedia Online: http://ojs.uniska.ac.id/index.php/BKA
e-ISSN 2477-6300

\title{
PENGARUH PERHATIAN ORANG TUA, PEMAHAMAN MATERI AQIDAH AKHLAK, DAN KEDISIPLINAN BELAJAR TERHADAP PERILAKU PESERTA DIDIK MTs NEGERI 1 SEMARANG
}

\author{
Widya Novi Angga Dewi ${ }^{1}$, Banun Sri Haksasi², Slamet $^{3}$ \\ Fakultas Keguruan dan Ilmu Pendidikan, Universitas Ivet, Semarang, Jawa Tengah, Indonesia \\ E-mail: widyanovi311@gmail.com ${ }^{1}$, srihaksasibanun@gmail.com² ${ }^{2}$ slamet.doktor@gmail.com $^{3}$
}

\begin{abstract}
ABSTRAK
Tujuan penelitian adalah menganalisis pengaruh: 1) perhatian orang tua terhadap perilaku peserta didik; 2) pemahaman materi aqidah akhlak terhadap perilaku peserta didik; 3) kedisiplinan belajar terhadap perilaku peserta didik; dan 4) perhatian orang tua, pemahaman materi aqidah akhlak, dan kedisiplinan belajar terhadap perilaku peserta didik. Metode penelitian digunakan jenis kuantitatif dengan pendekatan eksplanatori bersifat asosiatif. Populasi penelitian adalah seluruh peserta didik kelas VII berjumlah 211 anak dengan tingkat kesalahan pengambilan sampel 5\% dari penerapan nomogram Harry King sehingga diperoleh 124 anak sebagai sampel. Alat pengumpulan data digunakan dokumentasi dan instrumen angket guna memperoleh jawaban dari variabel perhatian orang tua, pemahaman materi aqidah akhlak, kedisiplinan belajar, dan perilaku peserta didik, sedangkan teknik analisis data digunakan regresi linier berganda melalui pengolahan data bantuan dari program SPSS versi 21.00. Temuan hasil penelitian adalah: 1) perhatian orang tua berpengaruh positif dan signifikan terhadap perilaku peserta didik; 2) pemahaman materi aqidah akhlak berpengaruh positif dan signifikan terhadap perilaku peserta didik; 3) kedisiplinan belajar berpengaruh positif dan signifikan terhadap perilaku peserta didik; dan 4) perhatian orang tua, pemahaman materi aqidah akhlak, dan kedisiplinan belajar berpengaruh positif dan signifikan terhadap perilaku peserta didik.
\end{abstract}

Kata Kunci: Perhatian Orang Tua; Aqidah Akhlak; Kedisiplinan; Perilaku Peserta Didik

\begin{abstract}
The research objective was to analyze the effects of: 1) parental attention to student behavior; 2) understanding the material aqidah akhlak on the behavior of students; 3) discipline in learning the behavior of students; and 4) parental attention, understanding of the material aqidah morals, and discipline in learning the behavior of students. The research method used is a quantitative type with an associative explanatory approach. The study population was all class VII students totaling 211 children with a sampling error rate of 5\% from the application of the Harry King nomogram so that 124 children were obtained as samples. The data collection tools used documentation and questionnaire instruments to obtain answers from the variables of parental attention, understanding of material aqidah morals, learning discipline, and student behavior, while data analysis techniques used multiple linear regression through data processing assistance from the SPSS version 21.00 program. The findings of the research are: 1) parental attention has a positive and significant effect on the behavior of students; 2) understanding the material aqidah morals has a positive and significant effect on the behavior of students; 3) learning discipline has a positive and significant effect on student behavior; and 4) parental attention, understanding of the material aqidah morals, and learning discipline have a positive and significant effect on the behavior of students.
\end{abstract}

Keywords: Parents Attention; Aqidah Achlaq; Discipline; Students Behavior

Dipublikasikan Oleh :

UPT Publikasi dan Pengelolaan Jurnal

Universitas Islam Kalimantan Muhammad Arsyad Al-Banjari Banjarmasin 
Widya Novi Angga Dewi, Banun Sri Haksasi, Slamet

Jurnal Bimbingan dan Konseling Ar-Rahman

Volume 6, Nomor 2, Tahun 2020

e-ISSN 2477-6300

\section{PENDAHULUAN}

Keluarga adalah tempat lahirnya anak. Dalam keluarga anak mendapatkan perhatian dari orang tua agar dapat menyesuaikan diri dengan lingkungan sosial melalui komunikasi keseharian. Demikian pula dengan studinya, orang tua menginginkan agar anak dapat berhasil dengan baik, maka anak perlu memiliki kedisiplinan dalam belajar (Azwar, 2012).

Pada keluarga yang mempunyai tingkat kehidupan sempurna, rasa tanggung jawab akan terasa lebih besar baik secara jasmani maupun rokhani, maka orang tua berusaha untuk memberikan fasilitas sesuai kemampuan agar kelak anak menjadi orang yang berguna bagi orang tua, agama, nusa, dan bangsa. Namun demikian ada juga sebagian orang tua yang kurang mempunyai rasa tanggung jawab, misalnya ada orang tua yang sampai hati membunuh anaknya atau memberikan kepada orang lain untuk dijual hanya untuk sekedar memenuhi kebutuhan jasmaniah. Kejadian semacam itu menggambarkan rasa tanggung jawab orang tua yang kurang (Darajat, 2011). Padahal fungsi dasar keluarga adalah memberikan rasa memiliki, rasa aman, rasa kasih sayang dan pengembangan hubungan yang baik diantara anggota keluarga. Oleh karenanya perhatian orang tua yang diberikan kepada anak sangat berpengaruh terhadap proses terbentuknya pribadi dan perilaku anak (Azwar, 2012).

Setiap anak memiliki kepribadian berbeda, hal tersebut dapat terjadi sebab proses terbentuknya kepribadian anak dalam keluarga juga berbeda sumbernya. Perhatian orang tua yang sehat perlu ditumbuhkembangkan secara integral dan dipandang perlu, sebab dalam setiap komunikasi dan bersosialisasi diperlukan pemahaman dan penerapan etika, tata nilai, sistem yang berlaku dalam kehidupan bermasyarakat, apalagi bagi negara-bangsa Indonesia yang plural, baik dilihat dari etnis, budaya, agama, bahasa, dan kewilayahan sehingga pemahaman terhadap nilai-nilai multikultural menjadi sebuah keniscayaan (Slamet, $\mathrm{dkk}, .2017)$.

Dalam dunia pendidikan, perhatian memiliki daya pengaruh besar terhadap perkembangan anak, baik terkait dengan belajar, perilaku, bersosialisasi, bahkan termasuk di dalamnya kedisiplinan dalam setiap tindakan (Partini, 2012). Perhatian mengawali "terjadinya perubahan energi pada diri setiap individu manusia, termasuk juga anak-anak. Perkembangan perhatian membawa perubahan energi yang ada pada organisme manusia, karena semuanya menyangkut perubahan energi manusia" (Handoko, 2014). Dalam kegiatan belajar seorang anak perlu diberikan perhatian, dorongan dari orang tua, karena pada suatu saat anak memiliki titik jenuh dan semangat yang lemah. Dalam hal ini orang tua berkewajiban memberikan pengertian, perhatian dan motivasi, serta berusaha membantu dalam pemecahan masalah belajar yang dihadapi anak. Jika diperlukan, orang tua melakukan komunikasi dengan guru bidang studi, wali kelas, guru BK, dan bahkan dengan Kepala sekolah untuk mengetahui tingkat perkembangan dan kemajuan belajar yang oleh anak.

Dimyati (2012) mengemukakan bahwa pada umumnya tingkat keberhasilan anak banyak ditentukan peran serta orang tua dalam mendidik, membina, dan melatih anak, baik dalam pikiran, perbuatan maupun perkataan. Ini berarti peran dan perhatian orang tua dalam mendisiplinkan belajar anak sangat diperlukan, hal tersebut dapat dikemukakan sebab keberhasilan yang dicapai anak juga merupakan salah satu tolak ukur keberhasilan orang tua. Proses tersebut dapat berlangsung dengan baik manakala kondisi keluarga dalam kondisi baik pula, sehingga memungkinkan terjadinya proses pengembangan guna memperluas dan penyaluran kemampuan serta potensi dan bakat yang dimiliki anak. Begitu pentingnya orang tua dalam keluarga, hal itu seperti dipertegas oleh Dhakir (2012) yang mengemukakan bahwa kondisi suatu keluarga yang memungkinkan untuk dapat melakukan pendidikan, pembinaan, dan munculnya kedisiplinan belajar pada anak secara optimal pada umumnya merupakan keluarga yang lengkap strukturnya, yaitu keluarga yang terdiri dari ayah, ibu, dan anak.

Pemberian perhatian dan memotivasi agar anak selalu belajar merupakan salah satu kewajiban orang tua, selain juga harus meluangkan waktu untuk berkomunikasi dengan anak. Adanya komunikasi yang terjadi antara orang tua dengan anak dapat menciptakan suasana keakraban diantara anggota keluarga tersebut, sehingga orang tua dapat membina dan melakukan pendekatan secara pribadi yang pada akhirnya dapat membantu dalam pemecahan masalah yang dihadapi oleh anak.

Permasalahan dan gagasan yang ada pada anak diperlukan adanya komunikasi timbal balik antara orang tua dengan anak, sehingga setiap pihak baik itu orang tua maupun anak dapat merasakan tugas dan tanggung jawabnya masingmasing. Melalui komunikasi timbal balik secara face to face (tatap muka langsung), sehingga situasi kondusif dalam rumah tangga dapat terjadi yang pada akhirnya memberikan perubahan sikap, perilaku, pola pikir, dan aktivitas mandiri kepada anak (Sutama, 2013). Oleh sebab itu perhatian orang tua bagi anak mutlak diperlukan demi perkembangan anak selanjutnya. 
Setiap orang tua mengharapkan anaknya kelak menjadi orang yang sukses, tetapi dalam kenyataannya tidak semua orang tua berhasil dalam mendidik, baik itu dari pendidikan agama, pendidikan formal, kepribadian, dan perilaku keseharian. Padahal pendidikan sangat menentukan dan berpengaruh pada masa depan anak. Secara sederhana pendidikan dapat dibedakan menjadi pendidikan formal, informal, dan non formal. Dalam kajian ini, pendidikan yang dimaksud adalah pendidikan formal, yaitu pendidikan yang berlangsung di MTs Negeri 1 Semarang.

Dalam pelaksanaan pendidikan tidak hanya bersifat penyampaian materi saja, tetapi juga adanya pembentukan perilaku dan kepribadian pada anak. Perlunya kepribadian bagi anak, sebab anak selalu beraktivitas dalam suasana heterogen, maka perilaku anak yang baik mutlak diperlukan. Bahkan semua orang tua mendambakan kepribadian dan perilaku anak yang baik ini terjadi pada anaknya, namun pada kenyataannya tidak semudah yang dipikirkan. Bermacam-macam sebab dan rintangan yang terjadi, memungkinkan sebagian orang tua mengalami rasa kecemasan dan kekhawatiran jika anaknya tidak memiliki kepribadian dan perilaku yang baik. Oleh sebab itu orang tua harus memberi perhatian serius, agar kepribadian dan perilaku anak dapat dimiliki untuk diterapkan dalam aktivitas kesehaian, baik dalam keluarga, sekolah, maupun dalam masyarakat (Hendrarno, 2011).

Berbicara masalah perhatian orang tua, perilaku dan kepribadian anak maka bisa ke arah negatif dan juga positif. Arah negatif, bila anak tidak mengindahkan segala sesuatu yang disampaikan oleh orang tua, baik itu berupa aturan agama, norma yang berlaku dalam masyarakat dan aturan yang ditetapkan negara (pelanggaran hukum). Sebaliknya anak akan berperilaku positif manakala segala sesuatu yang disampaikan oleh orang tua dapat dipahami dan dilakukan serta diterapkan secara baik, termasuk pada peserta didik di MTS Negeri 1 Semarang.

Kondisi di lapangan menunjukkan bahwa pada umumnya anak, termasuk juga peserta didik di MTs Negeri 1 Semarang ada yang memiliki kepribadian dan perilaku yang menyimpang dari aturan yang telah ditetapkan sekolah dan aturan agama. Anak suka melakukan pelanggaran terhadap tata tertib sekolah, tidak disiplin dalam pengumpulan tugas dan pentaatan waktu belajar, suka ramai di dalam kelas bila ada jam kosong, suka minta perhatian dengan membuat ulah dan gaduh saat pembelajaran berlangsung, dan tindakan penyimpangan lain yang perlu segera untuk dihentikan, sebab bila tidak dikhawatirkan akan berpengaruh pada teman lain, bahkan yang ditakutkan akan melakukan pelanggaran lebih jauh. Akibatnya anak mengalami kegagalan, baik dalam studi maupun dalam kehidupan sehari-hari dan kelak, apalagi dalam kehidupan beragama. Kejadian semacam itu tentu dikhawatirkan oleh semua pihak apalagi bagi orang tua, sedangkan bagi guru juga ikut merasa khawatir dan merasa bertanggungjawab secara moral untuk dapat menyelesaikan dan menghentikan perilaku sebagai perwujudan dari kepribadian anak yang menyimpang tersebut. Hal itu bila di sekolah menjadi garapan dari Kepala sekolah dan guru, termasuk di dalamnya guru Aqidah Akhlak, namun bila anak lepas dari sekolah, tentu hal ini menjadi tugas dan tanggung jawab serta perhatian dari orang tua. Dengan demikian perhatian orang tua ikut menentukan perilaku anak dan juga guru pengampu mata pelajaran Aqidah Akhlak, sebab pesan moral yang disampaikan guru dapat belum tepat pada sasaran sehingga tujuan pembelajaran yang ingih dicapai belum maksimal.

Aqidah Akhlak merupakan pedoman bagi seseorang baik secara pribadi maupun kelompok untuk melakukan perbuatan dalam kehidupan sehari-hari yang baik. Aqidah Akhlak juga berisi anjuran-anjuran yang harus dilakukan dan laranganlarangan yang harus dihindarkan. Manusia yang taat dan patuh terhadap agama yang dianut, tentu akan melakukan tindakan-tindakan yang sesuai dengan etika, norma dan aturan agama, serta aqidah akhlak, sedangkan bagi anak yang tidak taat terhadap agama yang dianutnya, maka akan cenderung melakukan penyimpanganpenyimpangan (Masyur, 2011).

Gambaran di atas menunjukkan adanya dua hal yang berbeda, satu sisi ada nilai-nilai positif yang terbentuk dari perhatian orang tua yang berakibat pada kepribadian dan perilaku anak yang baik. Mata pelajaran Aqidah Akhlak yang disampaikan oleh guru belum dapat dipahami, dihayati dan dilaksanakan oleh peserta didik secara maksimal dan benar, bahkan dapat dikatakan bahwa ada sebagian anak yang masih suka melakukan penyimpangan terhadap etika, norma dan aturan agama, tentu bukan menjadi harapan dari orang tua dan guru, sehingga keduanya baik orang tua maupun guru perlu mawas diri, saling memfungsikan sesuai porsinya masing-masing agar anak memiliki kepribadian dan perilaku yang baik. Dengan demikian muncul sebuah pertanyaan: apakah perhatian orang tua dan pemahaman materi Aqidah Akhlak yang disampaikan oleh guru memiliki pengaruh terhadap kedisiplinan dalam belajar serta berdampak pada perilaku anak? Hal inilah yang mendorong peneliti tertarik untuk mengadakan penelitian dengan judul semacam ini, sehingga rumusan masalah penelitian ini adalah: 1) 
Widya Novi Angga Dewi, Banun Sri Haksasi, Slamet

Jurnal Bimbingan dan Konseling Ar-Rahman

Volume 6, Nomor 2, Tahun 2020

e-ISSN 2477-6300

bagaimana pengaruh perhatian orang tua terhadap perilaku peserta didik?; 2) bagaimana pengaruh pemahaman materi aqidah akhlak terhadap perilaku peserta didik?; 3) bagaimana pengaruh kedisiplinan belajar terhadap perilaku peserta didik?; dan 4) bagaimana pengaruh perhatian orang tua, pemahaman materi aqidah akhlak, dan kedisiplinan belajar terhadap perilaku peserta didik MTs Negeri 1 Semarang?

\section{METODE}

Jenis penelitian digunakan pendekatan kuantitatif dengan desain tipe eksplanatori yang bersifat asosiatif dengan analisis regresi berganda (Arikunto, 2012). Model analisis regresi berganda dapat dilakukan estimasi besarnya hubungan kausal antar sejumlah variabel dan hirarki kedudukan masing-masing variabel dalam serangkaian hubungan kausal atau sebab-akibat(Singarimbun, 2012).

Populasi dalam penelitian adalah seluruh peserta didik kelas VII yang berjumlah 211 anak dengan sampel 124 anak melalui tingkat kesalahan pengambilan sampel $5 \%$ dari penggunaan nomogram Harry King. Alat pengumpulan data digunakan dokumentasi dan kuesioner/angket (Faisal, 2013). Angket sebagai alat pengumpul data utama digunakan untuk mengkaji keempat variabel, yaitu: 1) perhatian orang tua (X1); 2) materi pelajaran aqidah akhlak (X2); 3) kedisiplinan belajar (X3); dan 4) perilaku peserta didik (Y).

Sebelum instrumen angket digunakan untuk pengumpulan data di lapangan, terlebih dahulu dilakukan uji instrumen dan semuanya telah memenuhi syarat validitas dan reliabilitas, karena beberapa item pernyataan yang tidak memenuhi kriteria validitas telah dibuang untuk diganti dengan item pernyataan yang baru. Teknik analisis data digunakan analisis regresi linier berganda melalui tahapan uji normalitas, uji hipotesis, uji koefisien persamaan garis regresi, dan uji koefisien determinasi guna pengambilan keputusan untuk menerima atau menolak hipotesis. Hipotesis yang diajukan dalam penelitian ini adalah hipotesis kerja (Ha), yaitu: 1) perhatian orang tua berpengaruh

positif dan signifikan terhadap perilaku peserta didik; 2) pemahaman materi aqidah akhlak berpengaruh positif dan signifikan terhadap perilaku peserta didik; 3) kedisiplinan belajar berpengaruh positif dan signifikan terhadap perilaku peserta didik; dan 4) perhatian orang tua, pemahaman materi aqidah akhlak, dan kedisiplinan belajar berpengaruh positif dan signifikan terhadap perilaku peserta didik.

Guna mempermudah proses perhitungan, maka digunakan alat bantu program SPSS versi 21 . Rumus analisis regresi linier berganda (Sudjana, 2012) secara manual dapat dituliskan sebagai berikut.

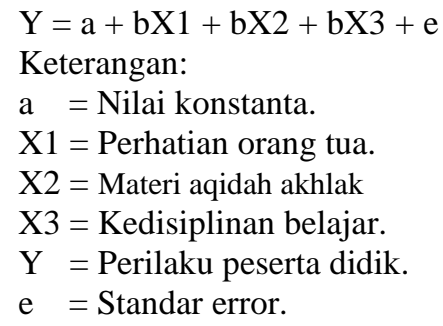

\section{HASIL DAN PEMBAHASAN}

Secara keseluruhan hasil penelitian pengaruh setiap variabel $\mathrm{X}$ (X1, X2, dan X3) terhadap Y dapat direkap dan disajikan pada tabel 1 berikut.

Tabel 1. Perhitungan Anova

\begin{tabular}{lccccc}
\hline \multicolumn{1}{c}{ Model } & $\begin{array}{c}\text { Sum of } \\
\text { Squares }\end{array}$ & df & $\begin{array}{c}\text { Mean } \\
\text { Square }\end{array}$ & F & Sig. \\
\hline Regression & 23.773 & 1 & 23.773 & 25.760 & .002 \\
Residual & 1120.815 & 119 & 13.504 & & \\
\hline Total & 1144.588 & 120 & & & \\
\hline
\end{tabular}

Berdasarkan tabel ANOVA di atas dapat diketahui bahwa nilai variabel perilaku peserta didik (Y) dapat dijelaskan variasi nilai variabel $\mathrm{X}$ $(\mathrm{X} 1, \mathrm{X} 2$, dan $\mathrm{X} 3$ ) dengan nilai $\mathrm{F}=25,760$, sedangkan besarnya signifikan 0,002 < 0,05, dengan demikian hipotesis kerja dapat diterima. Adapun pengaruh dari setiap variabel $\mathrm{X}(\mathrm{X} 1, \mathrm{X} 2$, dan X3) terhadap variabel Y dapat disajikan seperti pada tabel 2 berikut. 
Tabel 2. Koefisien

\begin{tabular}{|c|c|c|c|c|c|}
\hline Model & $\begin{array}{l}\text { Unstan } \\
\text { Coe } \\
\mathrm{B}\end{array}$ & $\begin{array}{l}\text { rdized } \\
\text { ents } \\
\text { Std. } \\
\text { Error }\end{array}$ & $\begin{array}{c}\text { Standardized } \\
\text { Coefficients }\end{array}$ & $\mathrm{t}$ & Sig. \\
\hline (Constant) & 80.719 & 2.811 & & 28.713 & .000 \\
\hline Perhatian Orang Tua & .254 & .043 & .313 & 4.922 & .000 \\
\hline Materi Aqidah Akhlak & .243 & .049 & .321 & 3.981 & .000 \\
\hline Kedisiplinan Belajar & .230 & .047 & .354 & 3.327 & .016 \\
\hline
\end{tabular}

a. Dependent Variable: Perilaku Keseharian.

Berdasar sajian tabel koefisien di atas dapat diberikan pembahasan setiap ajuan permasalahan sebagai berikut.

\section{Pengaruh perhatian orang tua terhadap perilaku Anak}

Pengaruh perhatian orang tua terhadap perilaku keseharian peserta didik ini diperoleh hasil beta standar sebesar 0,313 dengan signifikan $0,000.0,000<0,05$, hal ini dapat diberikan penjelasan bahwa perhatian orang tua memiliki pengaruh positif dan signifikan terhadap perilaku keseharian peserta didik sebesar 0,313 atau 31,1\%. Hasil tersebut dapat dijabarkan lebih jauh bahwa perhatian orang tua yang diberikan dapat membangkitkan peserta didik untuk berperilaku dalam kegiatan seharian secara positif. Hal tersebut menunjukkan adanya pengaruh perhatian orang tua terhadap perilaku keseharian peserta didik. Pengaruh ini didukung oleh hasil hitung $\mathrm{F}=25,760$ pada signifikan 0,002, karena 0,002 <0,05 Crobach Alpha, maka hipotesis yang diajukan: ada pengaruh positif dan signifikan perhatian orang tua terhadap perilaku keseharian peserta didik MTs Negeri 1 Semarang diterima. Pengaruh tersebut didukung uji koefisian persamaan garis regresi yang diperoleh konstan $(a)=80,719$, sedangkan nilai $b$ $=0,254$, sehingga: 80,719+0,254X1 = 87,395.

Koefisien b disebut sebagai koefisien arah regresi dan sebagai perubahan rata-rata variabel $\mathrm{Y}$ untuk setiap perubahan variabel $\mathrm{X} 1$ sebesar satu unit. Hasil hitung tersebut dapat diterapkan bahwa setiap kali variabel X1 (perhatian orang tua) bertambah satu, maka rata-rata variabel Y (perilaku keseharian) juga bertambah 0,254. Dengan demikian tafsirnya sebesar 87,395 hal ini berarti bahwa besarnya nilai t dapat dijadikan petunjuk untuk mengetahui ada tidaknya pengaruh perhatian orang tua terhadap perilaku keseharian peserta didik, dalam hal ini terdapat pengaruh secara positif (+) sehingga hipotesis kerja: "ada pengaruh positif dan signifikan perhatian orang tua terhadap perilaku keseharian peserta didik MTs Negeri 1 Semarang" diterima. Hal ini memberikan gambaran bahwa semakin baik dan semakin serius perhatian orang tua yang diberikan kepada anaknya, maka akan semakin baik dan semkin meningkat perilaku keseharian yang dimiliki oleh para peserta didik MTs Negeri 1 Semarang. Hasil penelitian tersebut senada dengan penelitian pendahulu yang dilakukan oleh Siska (2013) dengan hasil: 1) terdapat pengaruh yang signifikan perhatian orang tua terhadap prestasi belajar siswa; 2) terdapat pengaruh yang signifikan motivasi belajar terhadap prestasi belajar siswa; dan 3) terdapat pengaruh perhatian orang tua dan motivasi belajar terhadap prestasi belajar Siswa SMA Negeri Jumapolo.

Penelitian pendahulu kedua yang senada dengan penelitian yang peneliti lakukan telah dilakukan oleh Wika (2013) dengan hasil bahwa: 1) ada pengaruh positif dan signifikan perhatian orang tua terhadap ketekunan belajar siswa ( $\mathrm{p}<$ $0,05)$; 2) ada pengaruh positif dan signifikan pergaulan siswa terhadap ketekunan belajar $(\mathrm{p}<$ $0,05) ; 3$ ) ada pengaruh positif dan signifikan antara bimbingan belajar terhadap ketekunan belajar siswa ( $<<0,05)$; 4) ada pengaruh positif dan signifikan perhatian orang tua, pergaulan siswa, dan bimbingan belajar di sekolah terhadap ketekunan belajar ( $\mathrm{p}<0,05)$; dan 5) tingkat perhatian orang tua $=73,09 \%$; pergaulan $=76,66 \%$; bimbingan belajar $=71,87 \%$; dan ketekunan belajar siswa $=74,05 \%$.

\section{Pengaruh Pemahaman Materi Aqidah Akhlak terhadap Perilaku Anak}

Pengaruh pemahaman materi aqidah akhlak terhadap perilaku peserta didik diperoleh skor beta standar 0,321, dengan signifikan 0,000. 0,000< 0,05 , hal ini dapat diberikan penjelasan bahwa pemahaman materi aqidah akhlak memiliki pengaruh positif dan signifikan terhadap perilaku peserta didik sebesar 0,321 atau $32,1 \%$. Hasil tersebut dapat dijabarkan bahwa pemberian materi aqidah akhlak dapat memberikan kontrubisi positif bagi peserta didik dalam berperilaku dalam kegiatan keseharian secara positif. Hal tersebut dapat dijelaskan bahwa perilaku keseharian peserta didik 
Widya Novi Angga Dewi, Banun Sri Haksasi, Slamet

Jurnal Bimbingan dan Konseling Ar-Rahman

Volume 6, Nomor 2, Tahun 2020

e-ISSN 2477-6300

dapat dipengaruhi oleh kuatnya pemahaman materi aqidah akhlak yang disampaikan oleh guru kepada peserta didik dalam peningkatan perilaku keseharian secara positif.

Berdasar hasil hitung menunjukkan adanya pemahaman materi aqidah akhlak terhadap perilaku keseharian peserta didik. Pengaruh ini didukung oleh hasil hitung $\mathrm{F}=25,760$ pada signifikan 0,002 , karena $0,002<0,05$ Crobach Alpha, maka hipotesis yang diajukan: ada pengaruh positif dan signifikan pemahaman materi aqidah akhlak terhadap perilaku keseharian peserta didik MTs Negeri 1 Semarang diterima. Pengaruh tersebut didukung uji koefisian persamaan garis regresi diperoleh nilai konstan $(\mathrm{a})=80,719$, sedang nilai $\mathrm{b}$ $=0,243$, sehingga: $80,719+0,243(X 2)=85,651$.

Koefisien b disebut sebagai koefisien arah regresi dan sebagai perubahan rata-rata variabel X2 untuk setiap perubahan variabel Y sebesar satu unit. Hasil hitung tersebut dapat diterapkan bahwa setiap kali variabel X2 (pemahaman materi aqidah akhlak) bertambah satu, maka rata-rata variabel Y (perilaku keseharian peserta didik) juga bertambah 0,243. Dengan demikian tafsirnya sebesar 85,651, ini berarti bahwa besarnya nilai $\mathrm{t}$ dapat dijadikan petunjuk untuk mengetahui ada tidaknya pengaruh pemahaman materi aqidah akhlak terhadap perilaku keseharian peserta didik, dalam hal ini terdapat pengaruh secara positif (+) sehingga hipotesis kerja: "ada pengaruh positif dan signifikan pemahaman materi aqidah akhlak terhadap perilaku keseharian peserta didik MTs Negeri 1 Semarang" diterima. Hal ini memberikan gambaran bahwa semakin baik dan semakin meningkat pemahaman materi aqidah akhlak maka akan semakin baik dan semain positif perilaku keseharian yang dimiliki dan dilakukan oleh peserta didik. Hasil penelitian tersebut sejalan penelitian pendahulu yang dilakukan Dewi (2016) yang menunjukkan bahwa: 1) implementasi pendidikan karakter pada perencanaan mata pelajaran akidah akhlak masih bersifat mengkarakterkan perencanaan pembelajaran dan belum menunjukkan perencanaan pembelajaran yang berkarakter; dan 2) implementasi dalam pelaksanaan masih bersifat konvensional.

\section{Pengaruh Kedisiplinan Belajar terhadap Perilaku Anak}

Pengaruh kedisiplinan belajar terhadap perilaku keseharian peserta didik diperoleh skor beta standar sebesar 0,354, hal ini menunjukkan bahwa kedisiplinan belajar yang dimiliki oleh peserta didik di MTs Negeri 1 Semarang berpengaruh positif dan signifikan terhadap perilaku keseharian peserta didik. Atau dapat dikatakan bahwa perilaku keseharian peserta didik dipengaruhi dan disebabkan oleh kedisiplinan belajar yang dimilikinya. Hal itu dapat dijelaskan bahwa perilaku keseharian peserta didik dapat dipengaruhi oleh kuatnya kedisiplinan belajar yang dilakukan oleh anak. Kedisiplinan belajar dapat dijelaskan melalui indikator yang mengkajinya, seperti: disiplin waktu dan disiplin kegiatan. Indikator itulah yang menyebabkan anak memiliki kedisiplinan dalam belajar sehingga perilaku keseharian peserta didik dapat meningkat dengan baik dan positif.

Berdasarkan hasil hitung menunjukkan adanya kedisiplinan belajar berpengaruh positif terhadap perilaku keseharian peserta didik, pengaruh ini didukung oleh hasil hitung $\mathrm{F}=25,760$ pada signifikan 0,002, karena 0,002 <0,05 Crobach Alpha, maka hipotesis yang diajukan: ada pengaruh positif dan signifikan kedisiplinan belajar terhadap perilaku keseharian peserta didik MTs Negeri 1 Semarang diterima. Pengaruh tersebut didukung uji koefisian persamaan garis regresi diperoleh nilai konstan (a) $=80,719$, sedangkan nilai $\mathrm{b}=0,230$, sehingga: $80,791+10,35=$ 91,069 .

Koefisien b disebut sebagai koefisien arah regresi dan sebagai perubahan rata-rata variabel X3 untuk setiap perubahan variabel Y sebesar satu unit. Hasil hitung tersebut dapat diterapkan bahwa setiap kali variabel kedisiplinan belajar bertambah satu, maka rata-rata variabel perilaku keseharian juga bertambah 0,230. Dengan demikian tafsirnya sebesar 90,069, ini berarti bahwa besarnya nilai $\mathrm{t}$ dapat dijadikan petunjuk untuk mengetahui ada tidaknya pengaruh kedisiplinan belajar terhadap perilaku keseharian peserta didik, dalam hal ini terdapat pengaruh secara positif (+) sehingga hipotesis kerja: "ada pengaruh positif dan signifikan kedisiplinan belajar terhadap perilaku keseharian peserta didik MTs Negeri 1 Semarang" diterima. Hal tersebut memberikan gambaran bahwa semakin baik kedisiplinan belajar yang tercipta dan dimiliki oleh peserta didik, maka akan semakin meningkat dan semakin baik perilaku keseharian yang dimiliki oleh peserta didik.

Hasil penelitian tersebut senada dengan penelitian pendahulu yang dilakukan oleh Bambang (2010) dengan diperoleh hasil bahwa terdapat pengaruh yang positif dan signifikan disiplin belajar terhadap prestasi belajar yang dicapai siswa dengan r hitung 0,894 lebih besar dari r tabel 0,254. Dengan demikian dapat disimpulkan bahwa tingkat kedisiplinan siswa dalam belajar merupakan salah satu faktor yang ikut memengaruhi terhadap prestasi belajar siswa, maka semakin tinggi tingkat disiplin belajar akan semakin tinggi prestasi belajar yang dicapai peserta didik.

Hasil penelitian berikut juga mendukung hasil penelitian peneliti. Penelitian dilakukan oleh Rennisa (2015) dengan hasil menunjukkan bahwa 
ada hubungan positif dan signifikan persepsi perhatian orang tua dengan prestasi belajar Kelas $X$ IPS SMA Negeri di Kota Magelang. Nilai kontribusi variabel persepsi perhatian orang tua terhadap prestasi belajar 36,59\%, sedangkan nilai kontribusi variabel kedisiplinan belajar terhadap prestasi belajar $44,41 \%$, dan nilai kontribusi variabel persepsi perhatian orang tua dan kedisiplinan belajar terhadap prestasi belajar sebesar $81 \%$.

\section{Pengaruh Perhatian Orang Tua, Pemahaman Materi Aqidah Akhlak, dan Kedisiplinan Belajar terhadap Perilaku Anak}

Pengaruh perhatian orang tua, pemahaman materi aqidah akhlak, dan kedisiplinan belajar terhadap perilaku keseharian peserta didik diperoleh skor beta standar $=0,313+0,321+$ $0,354=0,988$, hal itu menunjukkan bahwa perhatian orang tua, pemahaman materi aqidah akhlak, dan kedisiplinan belajar yang tercipta dan dimiliki oleh peserta didik di MTs Negeri 1 Semarang berpengaruh positif dan signifikan terhadap perilaku keseharian, atau dapat dikatakan bahwa perilaku keseharian peserta didik dipengaruhi dan disebabkan oleh perhatian orang tua, pemahaman materi aqidah akhlak, dan kedisiplinan belajar peserta didik. Hal tersebut dapat dijelaskan bahwa perilaku keseharian peserta didik dapat dipengaruhi kuatnya perhatian orang tua, pemahaman materi aqidah akhlak, dan kedisiplinan belajar peserta didik dengan berbagai dimensi dan indikator yang mengupasnya.

Berdasarkan hasil hitung menunjukkan adanya pengaruh positif antara perhatian orang tua, pemahaman materi aqidah akhlak, dan kedisiplinan belajar terhadap perilaku keseharian peserta didik. Pengaruh ini didukung oleh hasil hitung $\mathrm{t}=28,713$ pada signifikan 0,000, karena $0,000<0,05$ Crobach Alpha, maka hipotesis yang diajukan: ada pengaruh positif dan signifikan perhatian orang tua, pemahaman materi aqidah akhlak, dan kedisiplinan belajar terhadap perilaku keseharian peserta didik MTs Negeri 1 Semarang" diterima. Pengaruh tersebut didukung uji koefisian persamaan garis regresi diperoleh nilai konstan (a) $=80,719$, sedangkan nilai $b=0,313+0,321+0,354=0,988$ > 28,713 .

Koefisien b disebut sebagai koefisien arah regresi dan sebagai perubahan rata-rata variabel $\mathrm{X} 1$, $\mathrm{X} 2$, dan $\mathrm{X} 3$ untuk setiap perubahan variabel $\mathrm{Y}$ sebesar satu unit. Hasil hitung tersebut dapat diterapkan bahwa setiap kali variabel perhatian orang tua, pemahaman materi aqidah akhlak, dan kedisiplinan belajar bertambah satu, maka rata-rata variabel perilaku keseharian peserta didik juga bertambah 0,988. Dengan demikian tafsirnya sebesar 0,988, ini berarti bahwa besarnya nilai $t$ dapat dijadikan petunjuk untuk mengetahui ada tidaknya pengaruh perhatian orang tua, pemahaman materi aqidah akhlak, dan kedisiplinan belajar terhadap perilaku keseharian peserta didik, dalam hal ini terdapat pengaruh secara positif $(+)$ sehingga hipotesis kerja: "ada pengaruh positif dan signifikan perhatian orang tua, pemahaman materi aqidah akhlak, dan kedisiplinan belajar terhadap perilaku keseharian peserta didik MTs Negeri 1 Semarang" diterima.

Hal ini memberikan gambaran bahwa semakin baik perhatian orang tua, pemahaman materi aqidah akhlak, dan kedisiplinan belajar yang tercipta maka akan semakin meningkat dan semakin baik perilaku keseharian peserta didik MTs Negeri 1 Semarang. Hasil penelitian tersebut senada dengan penelitian pendahulu yang dilakukan oleh Annastasia (2015) dengan hasil menunjukkan bahwa remaja SMP memiliki lebih banyak problem emosi dan perilaku daripada remaja SMA $\mathrm{t}(566)=2,08 ; \mathrm{p}=0,038)$, terutama dalam hal bergaul $\mathrm{t}(566)=2,92 ; \mathrm{p}=0,004)$; berpikir $\mathrm{t}(566)=2,47 ; \mathrm{p}=0,014)$; keluhan somatik $\mathrm{t}(566)=2,98 ; \mathrm{p}=0,002)$; melanggar aturan $\mathrm{t}(566)$ $=6,63 ; \mathrm{p}<0,001)$; dan externalizing problem $\mathrm{t}(566)=3,37 ; \mathrm{p}=0,001)$. Perbedaan gender tampak pada perbedaan domain problem emosi subjek. Pada kelompok remaja SMP, perempuan pada umumnya memiliki lebih banyak problem emosi daripada laki-laki $\mathrm{t}(335)=-3,55 ; \mathrm{p}<0,001)$, terutama dalam hal kecemasan/depresi $\mathrm{t}(335)=$ $6,51 ; \mathrm{p}<0,001)$; menarik diri dari pergaulan $\mathrm{t}(335)$ $=-4,26 ; \mathrm{p}<0,001)$, keluhan somatik $\mathrm{t}(335)=$ $2,86 ; \mathrm{p}=0,004)$; kesulitan bergaul $\mathrm{t}(335)=-3,30$; $\mathrm{p}=0,001)$, memusatkan konsentrasi $\mathrm{t}(335)=-2,39$; $\mathrm{p}=0,017)$; dan externalizing problem $\mathrm{t}(335)=$ 5,76; $\mathrm{p}<0,001)$. Sedangkan pada remaja SMA, laki-laki lebih sering mengalami externalizing problem $\mathrm{t}(229)=2,10 ; \mathrm{p}=0,037)$ dan lebih banyak melanggar aturan $\mathrm{t}(229)=4,44 ; \mathrm{p}<0,001)$ dari pada perempuan. Sebaliknya, perempuan lebih sering mengalami keluhan fisik karena problem psikologis dari pada laki-laki $\mathrm{t}(229)=$

$-3,09 ; \mathrm{p}=0,001)$, maka dapat direkomendasikan bahwa problem emosi remaja, termasuk di dalamnya para peserta didik perlu mendapatkan perhatian serius dan penanganan sesegera mungkin dilakukan.

Selain hasil penelitian Anastasia (2015), dikemukakan pula hasil penelitian Fenia dan Yusiana (2012). Hasil penelitian menunjukkan bahwa ada korelasi positif dan signifikan perhatian orang tua dengan peningkatan kreativitas belajar peserta didik anak di SMP Negeri 1 BangsalBanyumas. Hasil penelitian diperoleh kesimpulan bahwa perhatian orang tua memiliki korelasi positif dan signifikan terhadap kreativitas belajar anak. 
Widya Novi Angga Dewi, Banun Sri Haksasi, Slamet

Jurnal Bimbingan dan Konseling Ar-Rahman

Volume 6, Nomor 2, Tahun 2020

e-ISSN 2477-6300

Hasil hitung korelasi diperoleh angka sebesar 0,463 , angka tersebut lebih besar dari tabel $r$ product moment pada $\mathrm{N}$ sebagai subjek $=96$ diperoleh angka 0,199 , karena $0,463>0,199$, maka hipotesis kerja: "Ada korelasi positif dan signifikan perhatian orang tua dengan peningkatan kreativitas belajar peserta didik" dapat diterima. Dengan penerimaan hipotesis kerja itu, maka dapat dikemukakan bahwa semakin baik perhatian orang tua yang diberikan kepada anaknya, maka akan diikuti dengan peningkatan atau kenaikan angka dari variabel kreativita belajar anak.

Berdasarkan hasil penelitian relevan yang telah dilakukan oleh peneliti sebelumnya, baik variabel perhatian orang tua, materi aqidah akhlak, maupun kedisiplinan belajar. Perbedaan mendasar dari penelitian sebelumnya dengan penelitian ini terletak pada variabel yang digunakan yaitu variabel perilaku keseharian anak dengan berbagai faktor dan dimensi yang dikupas secara mendalam melalui pernyataan-pernyataan dalam instrumen angket. Hasil penelitian diketahui ada pengaruh positif dan signifikan perhatian orang tua, pemahaman materi aqidah ahklak, dan kedisiplinan belajar terhadap perilaku keseharian anak. Pengaruh tersebut diketahui dari uji koefisian persamaan garis regresi diperoleh nilai konstan (a) $=80,719$, sedangkan nilai $\mathrm{b}=0,313+0,321+0,354$ $=0,988>28,713$, dengan demikian tafsirnya semakin baik perhatian orang tua, pemahaman materi aqidah akhlak, dan kedisiplinan belajar yang tercipta dan dimiliki oleh anak maka akan semakin meningkat dan semakin baik perilaku keseharian peserta didik MTs Negeri 1 Semarang.

\section{PENUTUP}

Kesimpulan yang diperoleh dari penelitian ini adalah: 1) perhatian orang tua memiliki pengaruh positif dan signifikan terhadap perilaku keseharian peserta didik, hal ini berarti bahwa semakin baik dan semakin serius orang tua memberikan perhatian kepada anak, maka akan diikuti dengan peningkatan perilaku anak dengan baik; 2) pemahaman materi aqidah akhlak memiliki pengaruh positif dan signifikan terhadap perilaku keseharian peserta didik, hal ini berarti bahwa semakin baik dan semakin serius guru melaksanaan proses pembelajaran pada materi aqidah akhlak, maka akan diikuti dengan peningkatan perilaku keseharian anak dengan baik; 3) kedisiplinan belajar memiliki pengaruh positif dan signifikan terhadap perilaku keseharian peserta didik, hal ini berarti bahwa semakin serius anak melakukan belajar dengan penuh kedisiplinan, maka akan diikuti dengan peningkatan perilaku keseharian anak dengan baik; dan 4) perhatian orang tua, pemahaman materi aqidah akhlak, dan kedisiplinan belajar memiliki pengaruh positif dan signifikan terhadap perilaku keseharian peserta didik, hal ini berarti bahwa semakin baik dan semakin serius orang tua memberikan perhatian kepada anak, anak memahami materi aqidah akhlak dengan baik, dan belajar dilakukan dengan penuh kedisiplinan, maka akan diikuti dengan peningkatan perilaku yang dimiliki oleh anak dnegan baik.

Berdasarkan kesimpulan yang diperoleh, saran diberikan kepada: 1) Kepala sekolah, untuk mengintensifkan kerja sama dengan orang tua guna peningkatan perhatian dan perilaku keseharian anak agar tidak melakukan penyimpangan baik etika, norma agama, dan peraturan yang ditetapkan oleh negara; 2) guru, disarankan memberikan motivasi guna peningkatan kedisiplinan belajar. Salah satu cara yang dapat dilakukan dengan memberikan hadiah atau penguatan walau hanya bentuk pujian, dan memberikan sanksi positif seperti meresume novel atau buku tertentu, menulis cerpen, pusisi, dan sebagainya; dan 3) bagi peserta didik untuk mengindahkan saran, baik dari orang tua maupun guru demi peningkatakan kedisiplinan belajar yang berakibat pada pencapaian prestasi belajar yang memuaskan, selain itu juga perlu memahami dan menerapkan nilai-nilai materi aqidah akhlak, karena didalamnya mengatur tentang perilaku manusia, baik hubungannya dengan Tuhan (baca: Allah SWT.) dan orang tua serta kepada sesama manusia.

\section{REFERENSI}

Annastasia, E. (2015). Profil Problem EmosiPerilaku pada Remaja Pelajar SMP-SMA dI Kota Semarang. Jurnal Psikologi Undip, 14 (2), 190-198.

Arikunto, S. (2012). Prosedur Penelitian: Suatu Pendekatan Praktik. Jakarta: Bumi Aksara.

Azwar, S. (2012). Sikap Manusia: Teori dan Pengukurannya, Yogyakarta: Pustaka Pelajar.

Bambang, S. (2010). Pengaruh Disiplin Belajar terhadap Prestasi Belajar Siswa Kelas XI SMK PGRI 4 Ngawi Tahun Pelajaran 2009/2010. Jurnal Media Prestasi, 6 (3), $117-131$.

Darajat, Z. (2011). Metodik Khusus Pengajaran Agama Islam. Jakarta: Bumi Aksara.

Dewi PS., (2016). Implementasi Pembelajaran Akidah Akhlak terhadap Pembentukan Karakter Siswa di MTs Negeri Semanu Gunungkidul. Jurnal Pendidikan Madrasah. 1 (2), 309-322. 
Widya Novi Angga Dewi, Banun Sri Haksasi, Slamet Jurnal Bimbingan dan Konseling Ar-Rahman

Volume 6, Nomor 2, Tahun 2020

e-ISSN 2477-6300

Dhakir, M. (2012). Dasar-dasar Psikologi, Yogyakarta: Fakultas Ilmu PendidikanUniversitas Negeri Yogyakarta.

Dimyati, M. (2012). Psikologi Pendidikan. Yogyakarta: Rake Press.

Faisal, S. (2013). Teknik Menyusun Instrumen. Surabaya: Usaha Nasional.

Fenia, Teviana dan Yusiana, M. Anita. (2012). "Pengaruh Perhatian Orang Tua terhadap Peningkatan Kreativitas Belajar Anak, Jurnal STIKES,5(1).

Handoko, M. (2014). Motivasi Daya Penggerak Tingkah Laku. Yogyakarta: Kanisius.

Hendrarno, E. (2011). Bimbingan dan Konseling di Sekolah. Semarang: UNNES Press.

Masyhur, K. (2011). Membaca Moral dan Akhlak Anak. Jakarta: Rineka Cipta.

Partini, S. (2012). Psikologi Sosial. Jakarta: FIPUniversitas Negeri Jakarta.

Rennisa, A. (2015). Hubungan Persepsi Perhatian dan Kedisiplinan Belajar terhadap Prestasi Belajar Siswa Kelas X IPS SMA Negeri di Magelang. Skripsi Tidak Dipublikasikan. Sarjana Fakultas Keguruan dan Ilmu Pendidikan Universitas Sebelas Maret, Surakarta.

Singarimbun, M. (2012). Metode Penelitian Survei. Jakarta: LP3ES.

Siska, EM., Susilaningsih, \& Nurhasan, H. (2013). Pengaruh Perhatian Orang Tua dan Motivasi Belajar terhadap Presatsi Belajar Siswa SMA Negeri Jumapolo. JUPE, 1 (3), 1-13.

Slamet, etc. 2017, The Implementation of Multicultural Values in The Education Institution, Journal of Education Development, 5(1).

Sudjana. (2012). Metoda Statistika. Bandung: Alfabeta.

Sutama, S. (2013). Psikologi Pendidikan. Bandung: Vrama Widya.

Wika, MS. \& Suparman. (2013). Pengaruh Perhatian orang Tua, Pergaulan Siswa, dan Bimbingaj Belajar di Sekolah terhadap Ketentuan Belajar Siswa Kelas XI-TGB SMK Negeri 1 Seyegan Yogyakarta. Jurnal Pendidikan Teknik Sipil dan Perencanaan, $1-4$ 